\title{
PERAN KIAI DAN USTADZ DALAM PEMIKIRAN FIQH SANTRI DI PONDOK PESANTREN AN-NAHDLAH MAKASSAR
}

\author{
Salahuddin Al Ayyubi \\ e-mail: andiaal88@gmail.com \\ Mahasiswa Pascasarjana UIN Alauddin Makassar
}

\begin{abstract}
Abstrak
Penelitian ini bertujuan untuk mengetahui: 1) metode yang digunakan dalam membangun pemikiran fiqh santri, 2) faktor pendukung dan penghambat peran kiai dan ustadz dalam pemikiran fiqh santri, dan 3) peran kiai dan ustadz dalam pemikiran fiqh santri. Penelitian ini merupakan penelitian kualitatid dengan pendekatan fenomenologi dan teknik pengolahan dan analisis data menggunakan analisis interaktif Miles dan Huberman. Hasil penelitian adalah 1) metode yang digunakan dalam membangun pemikiran fiqh santri yaitu mixed methods ialah metode tradisional dan metode yang telah diperbaharui. 2) faktor pendukung peran kiai dan ustadz dalam pemikiran fiqh santri yaitu kiai dan guru yang cukup berkualitas, dukungan orang tua, ketersediaan kitab dan metode yang digunakan serta lomba-lomba yang diadakan. Sedangkan, faktor penghambat yaitu kemampuan bahasa Arab santri, menemukan perbedaan individu santri, kurikulum madrasah dan fasilitas yang kurang mendukung. 3) peran kiai dan ustadz dalam pemikiran fiqh santri dapat diketahui pemikiran fiqh santri berpusat pada pimikiran fiqh NU yang mempertahankan dan mengembangkan ajaran Ahl al-Sunnah wa 'lJama 'ah, namun pada pembentukan keputusan tidak dapat dicapai oleh pemikiran fiqh santri dikarenakan pola pemikiran masih bersifat qauly (tekstual).

Kata Kunci: Kiai, Ustadz, Pemikiran, Fiqh
\end{abstract}

\section{Abstract}

This study aims to find out: 1) the methods used in building students' fiqh thinking, 2) supporting and inhibiting factors of the role of the kiai and religious teacher in students' figh thinking, and 3) the role of the kiai and religious teacher in students fiqh thinking. This research is a quality study with a phenomenological approach and data processing and analysis techniques using the interactive analysis of Miles and Huberman. The results of the study are 1) the method used in building the santri fiqh thinking, namely mixed methods, is the traditional method and the updated method. 2) the supporting factors of the role of the kiai and religious teacher in the fiqh of santri are the quality of the kiai and teacher, the support of 
parents, the availability of books and methods used and the competitions held. Meanwhile, the inhibiting factors are the ability of students to learn Arabic language, find differences in individual students, madrasa curriculum and facilities that are less supportive. 3) the role of the kiai and ustadz in santri fiqh thinking can be seen that santri figh thinking is centered on the NU fiqh thinking which maintains and develops the teachings of Ahl al-Sunnah wa 'l-Jamä'ah, but in the formation of santri fiqh thinking cannot be achieved because of the santri fiqh thinking thought is still qauly (textual).

Keywords: Kiai, Ustadz, Thinking, Fiqh

\section{A. Pendahuluan}

Pondok pesantren merupakan lembaga pendidikan keagamaan di Indonesia yang paling tua. Lembaga ini khusus mengkaji dan mengembangkan. Dalam perkembangannya, pondok pesantren tidak hanya fokus pada kajian, melainkan mengembangkan kajian ilmu-ilmu yang bersifat umum atau dikembangkan pada sekolah umum. ${ }^{1}$ Kemampuan pesantren membangun peradaban tidak bisa dilepaskan dari kiai dengan segala pemikiran dan karyanya sebagai tulang punggung pesantren. Peradaban agung merupakan barakah kiai yang tanpa lelah membangun pesantren, mengembangkan masyarakat, dan merawat tradisi intelektual-keilmuan yang mutawatir dari generasi ke generasi melalui transmisi kitab kuning. Melalui khazanah khas (genuine) dunia pesantren yang disebut kitab kuning, para kiai mampu menggerakkan bahkan menentukan laju perubahan zaman. Para kiai dengan kreatif menyelami dan mendalami gerak kehidupan yang dipahatkan dalam karya-karya tulis yang mengagumkan. Warisan kitab-kitab kuning selalu dikreasi untuk terus melaju dengan tantangan zaman. Kreasi tersebut berbentuk aneka ragam, mulai dari kitab syarah, khulasah, mukhtasar, hingga menulis kitab baru dalam beragam bahasa. Fiqh mendapatkan porsi terbesar di pesantren. Menurut Nurcholis Madjid, besarnya porsi fiqh karena keahlian dalam bidang ilmu itu berkaitan dengan kekuasaan, maka pengetahuan tentang hukum-hukum agama Islam merupakan tangga naik yang paling langsung menuju status sosial politik yang lebih tinggi. ${ }^{2}$

${ }^{1}$ Mukhtaruddin, 2011, “Standarisasi Penguasaan Kitab Kuning (Studi di Pondok Pesantren Al-Anwar Sarang, PPI API Magelang, dan PPI Al-Fadllu Kaliwungu)", Jurnal Analisa, Vol. XVIII, No. 02, hlm. 165.

${ }^{2}$ Andik Wahyun Muqoyyidin, "Kitab Kuning dan Tradisi Riset Pesantren di Nusantara", Jurnal Kebudayaan Islam, Vol. 12 No. 12, hlm. 123. 
Pemikiran fiqh selalu mengacu pada pola mazhab-mazhab yang dimana 4 mazhab yang cukup popular mempunyai pengaruh yang cukup signifikan terhadap perkembangan zaman hingga saat ini. Pergulatan pemikiran menjadi sebuah ciri khas dalam berijtihad, begitu pula dengan pergulatan pemikiran fiqh dalam Nahdatul Ulama. Pergulatan pemikiran dalam NU dengan ragam ekspresi pemikiran di atas tidak terlepas dari sikap ulama NU dalam memaknai adagium al-muhâfadhat 'alā al-qadīm al-shālih wa alakhdzu bi al-jadīd alashlah sebagai ruang dinamis NU. Adagium ini memposisikan NU pada dua kutub yang saling tarik-menarik. Satu sisi NU sebagai jam'iyyah dīniyyah meneguhkan pola bermadzhab dengan memegangi warisan klasik (al-turāts alqadīm), yakni kitab-kitab fiqh madzhab. Pada sisi yang lain, NU tidak bisa menghindar dari perubahan dan kemajuan hasil modernisasi, yakni karyakarya intelektual modern (Barat) sebagai al-turāts al-gharbī. Dengan kata lain, meminjam istilah Al-Jabiri, pergulatan pemikiran Islam (NU) berada pada sikap tarik-menarik antara warisan lama/klasik (al-turäts) dan modernitas (alhadātsah). ${ }^{3}$

Sikap pemikiran Islam yang lebih mengarah pada modernitas akan memberikan dampak apabila modernitas yang dianut berlebihan, hal ini akan menafikan nilai-nilai warisan klasik (al-turāts). Namun, diperlukan pemikiran yang tidak fanatik baik pada modernitas maupun warisan klasik, sebagaimana diketahui bahwa hukum Islam (fiqh) mempunyai sifat dinamis yaitu mengalami perubahan dari zaman ke zaman.

Kemudian, dewasa ini para pengamat dan para praktisi pendidikan dikejutkan dengan fenomena yang terjadi pada pondok pesantren yaitu (1) banyaknya lembaga pesantren yang tergusur sejak dilancarkannya perubahan atau modernisasi pendidikan Islam di berbagai kawasan dunia muslim dan sebagian lembaga pesantren pesantren tidak mampu bertahan, (2) banyaknya pesantren mengalami transformasi sehingga sebagian telah memasuki lembaga pendidikan umum, (3) banyaknya pesantren mengalami penurunan animo masyarakat sehingga mengakibatkan jumlah santri menurun setelah menyesuaikan diri dengan mengadopsi sedikit banyak isi dan metodologi pendidikan umum, (4) sebagian pesantren enggan dengan perubahan (dan lebih memilih menjaga budaya lama) dengan menolak masuknya kebijakan pemerintah melalui Kementerian Agama RI dan Kementerian Pendidikan dan

${ }^{3}$ Ahmad Arifi, 2009, "Dinamika Pemikiran Fiqh dalam NU: Analisis atas Nalar Fiqh Pola Mazhab”, Ulumuna: Jurnal Studi Keislaman, Vol. XIII No. 1, hlm. 191. 
Kebudayaan karena khawatir akan kehilangan karakter budaya organisasi lembaganya yang sudah mapan dan dipercaya masyarakat. ${ }^{4}$

Kiai dan ustadz memiliki peran dalam membangun pondok pesantren dan membentuk pemikiran-pemikiran fiqh yang dinamis yang sesuai dengan sumber-sumber hukum Islam (fiqh) tanpa melewatkan kemaslahatan masyarakat sekitar. Perubahan-perubahan yang berkembang akan merubah pemikiran-pemikiran fiqh santri dan masyarakat di era modern dan global saat ini, maka kiai dan ustadz harus memiliki peran dalam membangun pemikiran fiqh santri.

\section{B. Metode Penelitian}

Jenis penelitian ini adalah penelitian dalam kategori studi lapangan (field research), dan bersifat kualitatif yang menggunakan pendekatan fenomenologi. Pendekatan fenomenologi berupa membiarkan realitas mengungkapkan dirinya sendiri secara alami, melalui pertanyaan pancingan. Metode pengumpulan data menggunakan observasi, wawancara dan dokumentasi yang merupakan langkah yang penting dalam suatu penelitian untuk mendapatkan data. Teknik pengolahan data yang digunakan dalam penelitian ini adalah teknik kualitatif yang lebih menekakan analisisnya pada proses penyimpulan induktif serta pada analisis terhadap dinamika hubungan antar fenomena yang diamati dengan menggunakan logika ilmiah, serta penekannya adalah pada usaha menjawab pertanyaan penelitian melalui caracara berfikir dan argumentative. Analisis data yang menjadi acuan dalam penelitian ini mengacu pada beberapa tahapan yang dijelaskan Miles dan Huberman yaitu tahap pengumpulan data, reduksi data dan penyajian data. Untuk memeriksa keabsahan data penelitian dapat dilakukan dengan berbagai kegiatan yaitu melakukan perpanjangan pengamatan, peningkatan ketekunan dan tringulasi.

\section{Hasil dan Pembahasan}

\section{Metode yang Digunakan dalam Membangun Pemikiran Fiqh Santri}

Metode pembelajaran dapat diartikan sebagai cara-cara yang dipergunakan untuk menyampaikan ajaran sampai ke tujuannya. Ajaran adalah apa yang terdapat dalam kitab kuning atau kitab rujukan atau

${ }^{4}$ Andik Wahyun Muqoyyidin, 2014, "Kitab Kuning dan Tradisi Riset Pesantren di Nusantara", Jurnal Kebudayaan Islam, Vol. 12 No. 12, hlm. 128. 
referensi yang dipegang oleh lembaga tersebut. ${ }^{5}$ Adapun metode-metode yang diberikan dalam membangun pemikiran fiqh santri yaitu dengan menggunakan metode pembelajaran pondok pesantren pada umumnya yaitu bandongan dan sorogan. Kiai dan ustadz yang telah membacakan dan menerjemahkannya pada forum bandongan yang kemudian akan disimak dan dipahami dengan baik oleh para santri, biasanya santri akan mencatat beberapa teks-teks bahasa Arab yang masih belum diketahui dan dipahami arti teksnya di kitab kuningnya sendiri.

Metode bandongan juga biasanya dikenal dengan istilah halaqah, merupakan metode yang paling sering digunakan pada proses pemberian pemahaman di pondok pesantren. Penjelasan dan penjabaran yang didengar akan dicatat oleh santri di kitab kuningnya dengan memberikan catatan pada bagian atas halaman atau bagian samping sehingga santri dalam mengulang pelajaran kembali baik di sekolah maupun di rumah akan efisien dan efektif karena mempunyai catatan yang telah diuraikan sebelumnya.

Metode selanjutnya yaitu metode sorogan adalah metode yang dilakukan secara individu oleh santri untuk belajar kepada kiai. Menurut Karel Steenbrink dalam pelaksanaannya santri yang banyak itu datang bersama, kemudian antri menunggu giliran masing-masing. ${ }^{6}$ Dengan menggunakan metode ini, memungkinkan kiai dalam menangkap kompetensi seorang santri dengan baik dan adanya hubungan yang lebih erat antara santri dengan kiai. Namun, dalam pelaksanaannya tidak dapat dilaksanakan dengan maksimal karena adanya keterbatasan waktu dalam proses pengajian yang dilaksanakan. Kemudian, terdapat metode diskusi atau dikenal dengan istilah musyawarah atau bahtsu Al-Masāil. Metode ini memperkenankan para santri untuk membentuk kelompok agar dapat mendiskusikan suatu materi dalam kitab yang dibahas, kemudian dalam satu kelompok ditunjuklah seorang ketua kelompok agar dapat memimpin kelompok yang dibentuk. Melalui metode ini dapat mengasah pemikiran para santri dalam menganalisis, berpendapat, dan berpikir kritis dalam satu permasalahan yang dibahas di satu pengajian. Hal ini akan mengembangkan kompetensi santri dalam memahami satu masalah terutama dalam bidang

\footnotetext{
${ }^{5}$ Amrizal, 2016, "Eksistensi Tradisi Kajian Kitab Kuning dalam Lingkup Perubahan Sosial (Studi Kasus di Pesantren Darun Nahdhah, Darel Hikmah, dan Babussalam)", Jurnal Sosial Budaya, Vol. 13 No. 1, hlm. 78.

${ }^{6}$ Iys Nur Handayani, 2018, "Metode Sorogan dalam Meningkatkan Kemampuan Membaca Al-Qur'an pada Anak", Jurnal Ilmiah Tumbuh Kembang Anak Usia Dini, Vol. 3 No. 2, hlm. 106.
} 
ilmu fiqih. Para santri akan menganalisis terlebih dahulu hukum-hukum yang berubah karena waktu maupun tempat, santri akan menggunakan kaidah fiqih dalam menganalisis hukum yang berubah tersebut.

Selanjutnya, yaitu metode hafalan yaitu yang dikenal dengan metode tahfidz. Metode ini digunakan pada pengajian malam kelas MTs dan MA Salafiyah pondok pesantren An-Nahdlah Makassar yang dimana dipusatkan pada hafalan-hafalan para santri yaitu berupa hafalan juz amma, hafalan matan imrity, dan hafalan Hadis Arba'in. Hal ini guna untuk meningkatkan pemahaman dan mengamalkannya dalam kehidupan sehari-hari. Seseorang penghafal merupakan penjaga dan pemelihara yang baik dan termasuk dalam kumpulan orang-orang yang berilmu, sebagaimana dalam QS. Al'Ankabūt/29:49, yaitu:

Terjemahnya:

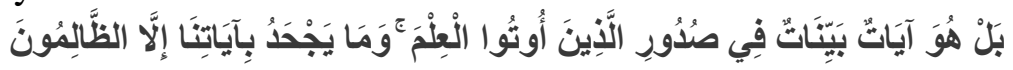

"Sebenarnya, al-Qur'an itu adalah ayat-ayat yang nyata di dalam dada orang-orang yang diberi ilmu. Dan tidak ada yang mengingkari ayat-ayat kami kecuali orang-orang yang zalim” (QS. Al-“Ankabūt/29:49)

Metode yang digunakan dalam melatih santri dalam membaca kitab kuning yang biasa digunakan pada kelas Salafiyah ialah metode al-Miftāh Lil 'Ulum. Metode ini merupakan rangkuman pada dari kitab al-Jurmiyyah, 'al-Imrițī dan Alfiyah. Dalam metode ini tidak dimunculkan istilah-istilah baru dalam 'Ilm al-nahw, bahkan tetap mempertahankan keoriginalitasan istilah dari kitab al-nahw klasik. Materi yang dikutip merupakan kaidahkaidah al-nahw dan al-șarf yang digunakan untuk keterampilan membaca kitab saja tanpa adanya pendalaman materi yang meluas dan panjang lebar. Konten dari metode al-Miftāh Lil 'Ulum memiliki karakteristik yang unik dimana materi yang ditampilkan dengan bahasa Indonesia yang lugas, jelas, singkat dan mudah dipahami. Kemudian, dilengkapi dengan rumus, ciri-ciri, tabel contoh dan skema materi yang disajikan dengan warna-warna yang bervariasi. Disisi lain, materi-materi ' $\mathrm{Ilm}$ al-nahw dan 'ilm al-ṣarfnya dikolaborasikan dengan lagu anak dan lagu daerah yang sudah sangat familiar. ${ }^{7}$ Metode al-Miftăh Lil 'Ulum ini digunakan oleh beberapa ustadz yang merupakan santri dari Jawa yang kemudian mengajar di pondok

${ }^{7}$ Ibnu Ubaidillah dan Ali Rif'an, 2019, "Efektivitas Metode Al-Miftah Lil 'Ulum dalam Meningkatkan Kualitas Membaca Kitab Kuning pada Santri Madrasah Diniah”, Jurnal Piwulang, Vol. 2, No. 1, hlm. 37. 
pesantren An-Nahdlah Makassar, yang dimana ustadz tersebut telah dilatih sebelumnya untuk memahami metode tersebut.

Selanjutnya, metode yang digunakan di pondok pesantren AnNahdlah Makassar yaitu metode muqoronah yang dimana metode ini menggunakan proses belajar dengan membandingkan materi atau sebuah paham atau madzhab-madzhab yang ada. Metode ini digunakan untuk menambah wawasan yang luas yang pada dasarnya pesantren An-Nahdlah Makassar lebih cenderung menggunakan madzhab Syafi'i dalam pemikiran fiqh. Dalam hal ini, kalangan Syafi'i menggolongkan sumber hukum menjadi dua bagian yaitu sumber hukum yang sah dan wajib diamalkan dan sumber hukum yang tidak sah dan tidak wajib untuk diamalkan. Menurut madzhab Syafi'i, sumber hukum yang sah yaitu al-Qur'an, sunnah, ijma', qiyas dan istishab. Sedangkan sumber hukum yang yang tidak sah dan tidak wajib untuk diamalkan yaitu istihsan, maslahah mursalah dan 'urf. Metode selanjutnya yaitu demonstrasi yang merupakan salah satu metode praktek yang juga digunakan dalam membangun pemikiran fiqh santri di pondok pesantren An-Nahdlah Makassar. Beberapa penjelasan yang diberikan, ada yang memerlukan praktek seperti shalat, bersuci dan lain sebagainya sebagaimana materi tersebut masuk dalam lingkup bidang ilmu fiqih.

Dengan demikian, pada pengamatan yang dilakukan dapat diketahui bahwa kiai dan ustadz memberikan peran yang sangat berguna dalam mengarahkan dan membimbing santri untuk memahami materi dibahas dalam beberapa metode yg digunakan di pondok pesantren An-Nahdlah makassar. Kiai dan ustadz serta santri saling berinteraksi secara langsung dan mempunyai peran yang aktif antara satu dengan yang lain. Metode yang digunakan ada yang metode tradisional dan ada pula yang pembaharuan, hal ini dapat dikatakan bahwa metode yang digunakan dalam membangun pemikiran fiqh santri adalah metode campuran (mixed methods).

\section{Faktor Pendukung dan Penghambat Peran Kiai dan Ustadz dalam Pemikiran Fiqh Santri}

Adapun faktor pendukung peran kiai dan ustadz dalam pemikiran fiqh santri di Pondok Pesantren An-Nahdlah Makassar, yaitu:

a) Kiai dan Ustadz yang cukup qualified

Pondok pesantren An-Nahdlah Makassar masih memiliki beberapa kiai dan ustadz yang cukup qualified dalam membangun fiqh santri meskipun gurutta Harisah selaku pimpinan pondok pesantren An- 
Nahldah yang awalnya hanya membentuk pengajian antar santri dan jama'ah hingga saat ini telah tiada, namun kiai dan ustadz di pondok pesantren dapat meningkatkan kembali proses pemberian pemahaman dengan berbagai macam ragam pengajian. Melalui latar belakang pendidikan kiai dan ustadz dapat mengindikasikan bahwa kiai dan ustadz selaku pengajar dan pendidik memiliki penguasaan secara mendalam kitab-kitab yang diajarkan serta metode pembelajaran dalam proses pemahaman yang diberikian kepada para santri. Melalui penguasaan kitab-kitab ini sehingga pondok pesantren An-Nahdlah Makassar memiliki potensi yang sangat besar dalam pengembangan dan pengorganisiran pondok pesantren dengan baik.

b) Dukungan orang tua para santri

Adapun salah satu faktor yang mendukung proses membangun pemikiran fiqh santri di pondok pesantren yaitu dengan adanya izin dan dukungan dari orang tua para santri. Melihat faktor dukungan orang tua para santri yang dimiliki dengan kuat dan diberikan bukan hanya dalam bentuk emosional namun juga dalam bentuk material baik dari memberikan dana (uang pendidikan), uang saku dan juga dukungan fasilitas seperti alat tulis dan lain sebagainya. Dengan faktor ini, santri memiliki potensi yang sangat besar untuk mengembangkan kompetensi yang disertai dengan minat untuk mendalami ilmu agama.

c) Ketersediaan kitab kuning

Ketersediaan kitab kuning di pesantren An-Nahdlah Makassar menjadi sebuah fasilitas utama dalam menjalankan sebuah pesantren, dikarenakan kitab kuning merupakan salah satu elemen penting pesantren. Kitab kuning di pesantren bukan hanya diperoleh dalam bentuk fisik namun juga dapat diperoleh dalam teknologi dengan mendownload kitab-kitab yang ada di aplikasi. Dengan beragamnya fasilitas yang diperoleh oleh para santri, hal ini cukup memudahkan dalam mendalami suatu kitab. Namun, dapat diketahui dengan adanya ketersediaan kitab kuning ini, para santri mesti tetap memperoleh proses pemahaman dari kiai dan ustadz sehingga santri mempunyai pengetahuan dan pemahaman yang kuat dan berwawasan luas dan menjadi alsunnah wal jamaah ala an-Nahdhiyah.

d) Metode yang digunakan

Faktor pendukung selanjutnya yang diperoleh santri dalam proses membangun pemikiran fiqh santri yaitu metode-metode 
pembelajaran yang digunakan di pondok pesantren An-Nahdlah Makassar. Metode-metode yang diberikan di pondok pesantren AnNahdlah Makassar yaitu metode campuran (mixed methods) yang dimana metode-metode tersebut berupa metode tradisional dan metode pembaharuan atau metode modern. Metode tradisional berupa bandongan, sorogan, dan hafalan, sedangkan metode modern berupa hiwar, bahtsul wasa'il, muqoronah, dan demonstrasi. Dengan metodemetode tersebut dapat meningkatkan ketertarikan para santri untuk mempelajari ilmu agama terutama dalam bidang ilmu fiqih yang paling banyak dipelajari, sehingga para santri tidak bosan dan malas untuk memahami ilmu tersebut.

e) Lomba-lomba

Faktor pendukung selanjutnya yaitu lomba-lomba yang diadakan sehingga mendorong antusias santri untuk membangun pemikiran fiqh santri lebih dalam dan luas. Dalam lomba-lomba yang diadakan lebih banyak berupa tahfidz al-Qur'an namun untuk dapat menjadi tahfidz maka harus memperoleh kelas salafiyah yang dominan diberikan pada pengajian malam berupa hafalan-hafalan juz 'amma. Santri dalam kelas salafiyah bukan hanya memperoleh hafalan namun juga pemahaman hukum Islam (fiqh), tauhid, aqidah, dan lain sebagainya. Melalui faktor pendukung ini, maka santri akan lebih termotivasi pada lomba-lomba yang diadakan bahkan lomba pada tingkat nasional. Pada satu titik, santri akan mencapai puncak kehausan ilmu yang tidak lain membawa diri para santri untuk memahami berbagai ilmu agama yang dipelajari di pondok pesantren An-Nahdlah Makassar, semata-mata karena ingin beribadah kepada Allah dengan mendekatkan diri melalui menuntut ilmu.

Sedangkan, faktor penghambat peran kiai dan ustadz dalam pemikiran fiqh santri di pondok pesantren An-Nahdlah Makassar, yaitu:

a) Kemampuan bahasa Arab santri yang masih perlu dibenahi

Beberapa santri yang tidak mondok di pesantren atau bolakbalik pulang ke rumah, memiliki kemampuan bahasa Arab yang sulit untuk dipantau oleh kiai dan ustadz yang menjadi pengajar dan pendidik serta pengasuh secara langsung di pondok pesantren AnNahdlah Makassar. Dengan sulitnya untuk dipantau tersebut sehingga kemampuan bahasa Arab santri masih perlu dibenahi, hal ini merupakan sebuah penyebab sehingga kemampuan bahasa Arab santri 
masih perlu untuk dibenahi. Lingkungan disekitar santri cukup mempengaruhi kemampuan bahasa Arab santri yang dimana lingkungan santri yang tidak homogen atau disebut dengan heterogen yaitu keanekaragaman lingkungan yang ada misalnya lingkungan yang dimana masyarakatnya minim akan pengetahuan ilmu agama dan juga kemampuan bahasa Arabnya.

b) Menemukan perbedaan individu santri

Faktor kedua yang menghambat yaitu menemukan perbedaan individu santri. Alat untuk memahami kitab kuning berkaitan dengan hukum Islam (fiqh) yaitu dengan mempelajari ' $\mathrm{Ilm}$ al-nahw dan 'ilm alșarf, karena ilmu inilah menjadi penyokong santri untuk dapat membaca kitab kuning dengan mudah dan baik. Dengan adanya perbedaan individu ini, diperlukan sebuah bimbingan khusus untuk santri yang masih dibawah rata-rata atau cara membaca kitab kuning yang masih perlu dibenahi. Bimbingan khusus yang dimaksud yaitu bimbingan yang dikelompokkan berdasarkan tingkat kemampuan santri dalam memahami kitab kuning.

c) Kurikulum madrasah

Faktor penghambat ini menjadikan pondok pesantren mengikuti kurikulum yang telah ditetapkan pemerintah sedangkan kurikulum tersebut masih mempunyai batasan-batasan, sehingga pemahaman santri di pondok pesantren tidak secara luas dan mendalam. Misalnya dalam mata pelajaran bahasa Arab, untuk kurikulum Kementerian Agama RI lebih banyak menggunakan muhadasiah dan penguasaan kaidah bahasa Arab tidak diperoleh. Dengan contoh kurikulum madrasah ini akan menghambat proses membangun pemikiran fiqh santri yang diperoleh dari kitab kuning, sedangkan kitab kuning yg diberikan diperlukan penguasaan bahasa Arab. Hal ini lah menjadi penghambat peran kiai dan ustadz dalam pemikiran fiqh santri di pondok pesantren.

d) Fasilitas Pondok Pesantren An-Nahdlah Makassar

Faktor penghambat selanjutnya yaitu fasilitas yang digunakan di pondok pesantren An-Nahdlah Makassar yang masih perlu ditingkatkan kembali untuk dapat menunjang proses pemahaman santri ke arah yang lebih modern seperti penggunaan AC atau kipas angin, computer dan lain sebagainya. Berdasarkan hasil wawancara dan observasi yang telah dilakukan memang terdapat beberapa fasilitas-fasilitas pondok 
pesantren An-Nahdlah Makassar yang memerlukan perhatian besar dari pihak pesantren maupun pihak pemerintah, sehingga pondok pesantren An-Nahdlah Makassar dapat berkembang dengan pesat dan dapat membangun pemikiran fiqh santri yang efektif sesuai dengan visi dan misi pondok pesantren An-Nahdlah Makassar.

\section{Peran Kiai dan Ustadz dalam Pemikiran Fiqh Santri}

Pondok pesantren An-Nahdlah Makassar dibawah kepemimpinan Alm. AGH. Muh. Harisah AS yang kemudian diteruskan oleh anaknya yaitu Afifuddin Harisah yang pada awalnya hanya berdiri sebagai bagian kegiatan pengajian dari 7 orang yang bertempatan di kediaman Alm. AGH. Muh. Harisah AS. Kegiatan pengajian ini berkembang menjadi sebuah pondok pesantren An-Nahdlah Makassar yang dimana memiliki pemikiran santri yang dipengaruhi oleh kepemimpinan Alm. AGH. Muh. Harisah AS yaitu pemikiran fiqh NU (Nahdatul Ulama) yang berdasarkan pada kitab-kitab fiqh 4 (empat) madzhab yang diikuti ialah Hanafi, Maliki, Syafi'i, dan Hanbali.

Pemikiran fiqh santri yang terbentuk di pondok pesantren tidak terlepas dari peran kiai dan ustadz yang menganut ajaran Ahl al-Sunnah wa 'l-Jamā'ah al Nahdiyyah yang kemudian mempengaruhi secara langsung pola pikir santri melalui kitab-kitab yang diberikan. Tahap proses berpikir mengenai fiqh ini dimulai dengan pembentukan pengertian, kemudian pembentukan pendapat dengan menghubungkan dua pengertian yang akan membentuk sebuah pendapat baik pendapat yang menolak, menerima maupun asumtif, dan yang terakhir yaitu pembentukan keputusan. Adapun uraian tahapnya sebagai berikut:

1. Pembentukan pengertian

Proses pembentukan pengertian ini dalam pemikiran fiqh santri diperoleh dari gambaran atau pengetahuan kiai dan ustadz berdasarkan pada pemahamannya mengenai ilmu fiqh melalui kitab-kitab ilmu fiqh yang diberikan di pondok pesantren An-Nahdlah Makassar. Untuk memahami dan mengerti isi kandungan dari kitab-kitab ilmu fiqh yang diberikan, diperlukan sebuah translasi atau mengetahui asal dari arti yang terkandung dalam teks-teks bahasa Arab yang tertulis didalam kitab tersebut yang sebagaimana kitab tersebut tidak memiliki syakl (fathah, kasrah, dhommah atau sukun), sehingga para santri diperkenankan untuk dapat belajar mengenai 'Ilm al-nahw dan 'ilm al-șarf yang kemudian 
akan digunakan dalam membaca dan mendapatkan gambaran atau pengetahuan akan teks-teks bahasa Arab dengan baik.

Pembentukan pengertian yang diberikan memang seharusnya terlebih dahulu proses mengartikan teks-teks bahasa Arab sehingga santri dalam membaca dan mengetahui suatu pemahaman kitab kuning tidak melenceng dari ajaran Islam. Kiai dan ustadz pondok pesantren AnNahdlah Makassar menekankan terlebih dahulu untuk mengetahui dan memahami dengan baik tata bahasa Arab

2. Pembentukan pendapat

Proses pembentukan pendapat ini dengan meletakkan hubungan antar dua pengertian yang kemudian akan membentuk sebuah pendapat mengenai fiqh santri di pondok pesantren. Dalam membangun pemikiran fiqh santri diperlukan sebuah proses menghubungkan syarh-syarh atau penjelasan dan penjabaran pada kitab yang diberikan kepada para santri di pondok pesantren An-Nahdlah Makassar yang merupakan proses dalam membentuk sebuah pendapat, sehingga pemikiran fiqh santri melalui proses pembentukan pemikiran ini sangat kompleks untuk menghindarkan dari pemikiran-pemikiran yang melenceng dari ajaran hukum Islam.

Dengan demikian, pembentukan pendapat dapat diperoleh dari menghubungkan pokok permasalahan hukum yang terjadi disekitar dengan informasi-informasi yang menjadi referensi dalam pembentukan pendapat, dan kemudian menghubungkan dengan sumber-sumber hukum Islam yaitu al-Qur'an, al-Sunnah, Qiyās dan 'Ijmā serta sumber hukum lainnya, syarh-syarh atau penjelasan dan penjabaran pada kitab, dan dengan menghubungkan 4 mazhab (hanafi, maliki, syafi'i dan hanbali).

Kiai dan ustadz memberikan pengaruh yang besar dalam pemikiran fiqh santri di pondok pesantren An-Nahdlah Makassar yang akan membentuk pengertian dan pendapat dalam diri santri yang kemudian menjadi pemikiran fiqh menganut ajaran Ahl al-Sunnah wa 'lJamā'ah untuk dipertahankan, dikembangkan, disebarkan dan ditegakkan dalam kehidupan sehari-hari dan masyarakat sekitar.

3. Pembentukan keputusan

Tahap ketiga yaitu pembentukan keputusan merupakan tahap penarikan kesimpulan yang akan menjadi pernyataan keputusan. Dalam pemikiran fiqh, pembentukan keputusan dapat dikatakan sebagai proses penetapan hukum setelah adanya tahap pengertian dan menghubung- 
hubungkan pengertian satu dengan yang lain baik melalui dalil-dalil, syarh-syarh, dan keempat mazhab yang popular tersebut untuk menetapkan hukum berdasarkan pokok permasalahan hukum yang membutuhkan penetapan hukum.

Proses penetapan hukum (istinbāth al-ahkām) yang dikenal dalam Bahtsul Masail NU berkembang 3 (tiga) metode, yaitu metode qauly, yakni pengambilan keputusan hukum dengan mengutip teks/redaksi pendapat dari ulama madzhab yang tertulis di dalam kitab-kitab fiqh madzhab, metode ilhāqy atau ilhāq al-masāil binadhāirihā, yakni dengan cara menganalogkan persoalan tersebut dengan masalah serupa yang sudah ada ketetapan hukumnya dalam kitab fiqh madzhab dan metode manhajy, yakni dengan melakukan istinbāth hukum menurut cara (manhaj) yang telah ditempuh oleh imam madzhab yang dikenal dengan sebutan bermadzhab secara manhajy. Adanya tiga macam metode istinbāth ini menunjukkan, bahwa pemikiran fiqh "tradisi" pola madzhab dalam NU, betapapun ciri tradisional yang melekat pada NU, dinamika pemikiran fiqh tetap terjadi. ${ }^{8}$

Pola pemikiran fiqh santri dengan metode penetapan hukum melalui Bahtsul Masail NU yang berkembang di pondok pesantren AnNahdlah Makassar masih mengarahkan santri pada metode berpikir secara tekstual (qauly) dan masih layaknya sebuah pesantren salaf yang dimana kitab-kitab yang diberikan dalam membangun pemikiran fiqh santri guna untuk mendalami materi yang terdapat pada kitab-kitab klasik yang diberikan. Adapun kitab-kitab yang digunakan untuk membangun pemikiran fiqh santri yang diantaranya yaitu, kitab Fath alQarib, Fath al-Mu'īn dan Al-Fawā'id al-Bahiyyah (Qawā'id Fiqih), Safinah al-Najā, Bulūg al-Marām dan Tanwìru al-Qulüb fì Mu'āmalah 'Allāmi al-Guyūb.

Pondok pesantren An-Nahdlah Makassar mengarahkan metode berpikir qauly untuk memperdalam materi yang terdapat di dalam kitabkitab klasik, hal ini dengan alasan santri yang terdapat di pondok pesantren merupakan kalangan siswa yang masih perlu dibenahi baik dari segi bahasa Arab dalam membaca dan mengucapkan maupun dalam penguasaan materi. Dengan demikian, pemikiran fiqh santri belum dapat

${ }^{8}$ Ahmad Arifi, 2009, "Dinamika Pemikiran Fiqh dalam NU: Analisis atas Nalar Fiqh Pola Mazhab”, Ulumuna: Jurnal Studi Keislaman, Vol. XIII, No. 1, hlm. 190. 
menduduki metode berpikir secara manhaj atau secara kontekstual dilihat pada kitab-kitab yang diberikan dalam membangun pemikiran fiqh santri hanya memberikan kitab Al-Sullam dan Tārīkh al-Tasyrī (sejarah pembentukan hukum Islam), sehingga masih minim pemikiran fiqh santri secara manhaj dan masih terarahkan pada pemikiran fiqh santri secara qauly

\section{Kesimpulan}

Berdasarkan rumusan masalah dan hasil penelitian yang telah diuraikan di bab sebelumnya dapat diperoleh kesimpulan pada tesis ini yang berjudul "Peran Kiai dan Ustadz dalam Pemikiran Fiqh Santri di Pondok Pesantren AnNahdlah Makassar", yaitu sebagai berikut:

1. Metode yang digunakan dalam membangun pemikiran fiqh santri di pondok pesantren An-Nahdlah Makassar yaitu metode campuran (mixed methods) yang dimana metode ini campuran dari metode tradisional diantaranya bandongan, sorogan, halaqah dan hafalan, kemudian metode yang telah mengalami pembaharuan yaitu bahtsu Al-Masāil, muqoronah, dan demonstrasi atau praktek.

2. Faktor pendukung dan penghambat peran kiai dan ustadz dalam pemikiran fiqh santri di Pondok Pesantren An-Nahdlah Makassar yaitu kiai dan guru yang cukup berkualitas, dukungan orang tua santri, ketersediaan kitab, metode yang digunakan dan lomba-lomba yang diadakan merupakan faktor pendukung peran kiai dan ustadz. Sedangkan, faktor penghambatnya yaitu kemampuan bahasa Arab yang masih perlu dibenahi, perbedaan individu santri, kurikulum madrasah dan fasilitas yang masih perlu ditingkatkan.

3. Peran kiai dan ustadz dalam pemikiran fiqh santri di pondok pesantren AnNahdlah Makassar dapat diketahui pemikiran fiqh santri berpusat pada pimikiran fiqh NU yang mempertahankan dan mengembangkan ajaran $A h l$ al-Sunnah wa 'l-Jamā'ah yang pada tahap berpikir yaitu 1) pembentukan pengertian, 2) pembentukan pendapat, namun pada 3) pembentukan keputusan tidak dapat dicapai oleh pemikiran fiqh santri dikarenakan pola pemikiran masih bersifat qauly (tekstual).

\section{Daftar Pustaka}

Amrizal, 2016, "Eksistensi Tradisi Kajian Kitab Kuning dalam Lingkup Perubahan

Sosial (Studi Kasus di Pesantren Darun Nahdhah, Darel Hikmah, dan Babussalam)", Jurnal Sosial Budaya, Vol. 13, No. 1. 
Arifin, Ahmad. 2009, "Dinamika Pemikiran Fiqh dalam NU: Analisis atas Nalar Fiqh Pola Mazhab", Ulumuna: Jurnal Studi Keislaman, Vol. XIII, No. 1.

Handayani, Iys Nur, 2018, "Metode Sorogan dalam Meningkatkan Kemampuan Membaca Al-Qur'an pada Anak", Jurnal Ilmiah Tumbuh Kembang Anak Usia Dini, Vol. 3 ,No. 2.

Mukhtaruddin, 2011, "Standarisasi Penguasaan Kitab Kuning (Studi di Pondok Pesantren Al-Anwar Sarang, PPI API Magelang, dan PPI Al-Fadllu Kaliwungu)", Jurnal Analisa, Vol. XVIII, No. 02.

Muqoyyidin, Andik Wahyun, 2014, "Kitab Kuning dan Tradisi Riset Pesantren di Nusantara”, Jurnal Kebudayaan Islam, Vol. 12, No. 12.

Ubaidillah, Ibnu dan Ali Rif'an, 2019, "Efektivitas Metode Al-Miftah Lil 'Ulum dalam Meningkatkan Kualitas Membaca Kitab Kuning pada Santri Madrasah Diniah”, Jurnal Piwulang, Vol. 2 No. 1. 